\title{
PERILAKU IBU PENGGUNA SMARTPHONE TERHADAP PERKEMBANGAN ANAK PRASEKOLAH DI TK HARAPAN I JAKARTA
}

\author{
Neli Husniawati ${ }^{2)}$, Nur Risma Ufadilla ${ }^{(2)}$ \\ Program studi S1 Keperawatan Universitas MH Thamrin \\ nelihusniawati39@gmail.com
}

\begin{abstract}
ABSTRAK
Indonesia menduduki peringkat pertama dalam penggunaan smartphone di Asia Tenggara dengan 57,7 juta pengguna dan berdasarkan jenis kelamin $76 \%$ penggunanya adalah wanita. Tujuan penelitian ini untuk mengetahui hubungan perilaku ibu pengguna smartphone terhadap perkembangan anak prasekolah di TK Harapan I. Penelitian ini menggunakan desain penelitian kuantitatif dengan rancangan penelitian cross sectional dan jumlah sampling sebanyak 94 reponden. Hasil penelitian didapatkan bahwa 45 responden memiliki perilaku penggunaan smartphone tinggi yaitu sebesar 55,6\% (25 orang). Untuk perkembangan anak sebagian besar perkembangan anak prasekolah mengalami Suspect yaitu sebesar $57,8 \%$ (26 orang). Dari hasil uji statistik didapatkan p-value $=0,014$ dan nilai OR $=5,881$ (95\% CI.1,605-21,552) sehingga dapat disimpulkan bahwa ada hubungan yang signifikan antara perilaku ibu pengguna smartphone terhadap perkembangan anak prasekolah di TK Harapan I. Kesimpulannya adalah perilaku ibu pengguna smartphone turut mempengaruhi terhadap perkembangan anak prasekolah. Diharapkan khususnya para ibu dapat menjadikan penelitian ini sebagai bukti yang dapat diterapkan dalam kehidupan sehari-hari sehingga para ibu termotivasi untuk menstimulus anak dengan menggunakan smartphone dengan bijak.
\end{abstract}

Kata Kunci: perilaku, ibu, smartphone, perkembangan anak prasekolah

Daftar Pustaka: 45 buah (2005-2017)

\section{PENDAHULUAN}

Angka penggunaan ponsel pintar atau smartphone meningkat pesat. Di Amerika Serikat mencapai 64\% dari penduduknya adalah pengguna smartphone. Indonesia sendiri berada pada peringkat pertama dalam daftar pengguna ponsel pintar atau smartphone terbesar Asia Tenggara dengan jumlah 57,5 juta pengguna. Penggunaan ini dilakukan untuk mengakses media sosial dari perangkat mobile dimana $76 \%$ wanita (Solutions, 2014). Berdasarkan usia presentase tertinggi penggunaannya yaitu pada usia 25-34 tahun sebanyak 35,8\% dan selanjutanya di peringkat kedua yaitu 31\% dengan usia 35-44 tahun dan di peringkat ketiga 26,9\% yang berusia 10-24 tahun. Penggunaan smartphone yang tidak terkontrol dapat mengganggu proses interaksi sosial, atau bahkan bisa jadi terisolasi dari lingkungan sosialnya, termasuk di dalam lingkungan sosial terdekatnya yaitu keluarga. Penggunaan barang ini dalam keluarga mempengaruhi keseluruhan interaksi sosial dalam keluarga tersebut dimana interaksi yang biasanya dilakukan antara orang tua pada anaknya sebagai bentuk pengasuhan dan komunikasi untuk menciptakan kekukuhan keluarga akan terganggu. Hal tersebut dikarenakan keluarga merupakan kesatuan sistem yang utuh, yang bila salah satu anggota keluarga mengalami kesulitan dalam melakukan interaksi secara langsung, hal tersebut membuat keluarga secara sadar atau tidak akan mengurangi atau melakukan perubahan dalam pola interaksi sosialnya. (Lestari, Riana \& Taftarzim, 2015). Menurut Lusina (2016) banyak waktu ibu yang tersita akibat sibuk dengan ponsel pintarnya atau smartphone sehingga waktu untuk anaknya berkurang dan ini akan berdampak kepada terhambatnya perkembangan.

Proses perkembangan anak terdapat masa kritis dimana diperlukan stimulasi atau rangsangan yang berguna terhadap potensi perkembangan sehingga perlu mendapat perhatian (Wulandari, Ichsan, Romadhon, 2016). Seorang anak bisa mengalami keterlambatan perkembangan di hanya satu aspek perkembangan saja, atau dapat pula di lebih dari satu aspek perkembangan. Keterlambatan perkembangan umum atau global developmental 
delay adalah keadaan keterlambatan perkembangan yang bermakna pada dua atau lebih aspek perkembangan. Secara garis besar, aspek perkembangan anak terdiri atas motor kasar, motor halus, bahasa/bicara, dan personal sosial/kemandirian. Sekitar 5 hingga 10\% anak diperkirakan mengalami keterlambatan perkembangan. Data angka kejadian keterlambatan perkembangan umum belum diketahui dengan pasti, namun diperkirakan sekitar 1-3\% anak di bawah usia 5 tahun mengalami keterlambatan perkembangan umum (Ikatan Dokter Anak Indonesia, 2013). Untuk mendapatkan perkembangan anak yang sesuai sebaiknya orang tua terus meningkat pengetahuan serta pemberian stimulasi yang adekuat dan sesuai kelompok umur, khususnya pada masa pertumbuhan emas balita (golden age) dan kurangnya pemberian stimulasi akan memberikan dampak yang sangat buruk terhadap tahapan perkembangan anak. 43,3\% ibu yang kurang memberikan stimulasi merupakan jumlah yang cukup besar (Nurlela, Nurchairina,2014).

Tujuan dari penenlitian ini untuk mengetahui adakah hubungan perilaku ibu pengguna smartphone terhadap perkembangan anak prasekolah. Berdasarkan uraian diatas, peneliti merasa tertarik melakukan penelitian tentang hal teserbut.

\section{METODE}

Metode penelitian yang digunakan adalah jenis penelitian kuantitatif dengan metode korelasi yaitu rancangan penelitian cross sectional dimana penelitian ini dengan melakukan pengukuran atau pengamatan pada saat bersama (sekali waktu) antara variabel independen dan variabel dependen (Nursalam, 2016).Populasi pada penelitian ini ialah murid dan orang tua dari TK Harapan I. Jumlah murid di TK tersebut sebanyak 47 orang. Teknik pengambilan sampel pada penelitian ini adalah dengan menggunakan total sampling yaitu semua anggota populasi dijadikan sebagai sampel penelitian. Jadi sampel pada penelitian ini adalah 47 anak yang TK di TK Harapan I dan ibu dari anak tersebut sehingga jumlah total keseluruhannya adalah 94 responden.

\section{HASIL}

Berdasarkan jumlah total responden yaitu sejumlah 45 didapatkan hasil data bahwa rata-rata usia responden adalah 30,29 tahun dengan standar deviasi 4,541. Usia termuda adalah 25 tahun dan usia tertua adalah 40 tahun. Dari hasil estimasi interval dapat disimpulkan bahwa 95\% diyakini rata-rata umur ibu adalah antara 28,92 tahun sampai dengan 31,65 tahun (Tabel 1)

Tabel 1

Distribusi Responden Berdasarkan Usia Di Tk Harapan I Tahun 2017

\begin{tabular}{ccccc}
\hline Variabel & Mean & SD & Min-Max & $\mathbf{9 5 \%}$ CI \\
\hline Usia & 30,29 & 4,541 & $25-40$ & $28,92-31,65$ \\
\hline
\end{tabular}


Tabel 2

Distribusi Responden berdasarkan pendidikan, sosial ekonomi, pekerjaan, perilaku ibu pengguna smartphone dan perkembangan anak prasekolah di TK Harapan I

Tahun 2017

\begin{tabular}{|c|c|c|c|}
\hline No & Variabel & $\begin{array}{l}\text { Frekuensi } \\
\text { (F) }\end{array}$ & $\begin{array}{c}\text { Persentase } \\
(\%)\end{array}$ \\
\hline \multirow[t]{3}{*}{1} & Pendidikan & & \\
\hline & a. Tamat SMP & 18 & 40,0 \\
\hline & b. Tamat SMA & 27 & 60,0 \\
\hline \multirow[t]{4}{*}{2} & Sosial ekonomi & & \\
\hline & a. $1.200 .000-2.300 .000$ & 22 & 48,9 \\
\hline & b. $2.300 .000-5.000 .000$ & & \\
\hline & & 23 & 51,1 \\
\hline \multirow[t]{3}{*}{3} & Pekerjaan & & \\
\hline & a. Tidak bekerja & 35 & 77,8 \\
\hline & b. Bekerja & 10 & 22,2 \\
\hline \multirow[t]{4}{*}{4} & $\begin{array}{c}\text { Perilaku ibu pengguna } \\
\text { smartphone }\end{array}$ & & \\
\hline & a. Rendah & & \\
\hline & b. Tinggi & 20 & 44,4 \\
\hline & & 25 & 55,6 \\
\hline \multirow[t]{3}{*}{5} & $\begin{array}{c}\text { Perkembangananak } \\
\text { prasekolah }\end{array}$ & & \\
\hline & a. Normal & 19 & 42,2 \\
\hline & b. Suspect & 26 & 57,8 \\
\hline
\end{tabular}

Tabel 3

Hubungan perilaku ibu pengguna smartphone dengan perkembangan anak prasekolah di TK Harapan I Tahun 2017

\begin{tabular}{|c|c|c|c|c|c|c|c|}
\hline & \multicolumn{4}{|c|}{$\begin{array}{c}\text { Perkembangan anak } \\
\text { prasekolah }\end{array}$} & \multirow{2}{*}{\multicolumn{2}{|c|}{ Total }} & \multirow[t]{3}{*}{$P$ value } \\
\hline & \multicolumn{2}{|c|}{ Normal } & \multicolumn{2}{|c|}{ Suspect } & & & \\
\hline & $\mathbf{N}$ & $\%$ & $\mathbf{N}$ & $\%$ & $\mathbf{N}$ & $\%$ & \\
\hline $\begin{array}{l}\text { Perilaku ibu } \\
\text { pengguna } \\
\text { smartphone }\end{array}$ & & & & & & & \\
\hline Rendah & 13 & 65,0 & 7 & 35,0 & 20 & 100 & 0,014 \\
\hline Tinggi & 6 & 24,0 & 19 & 76,0 & 25 & 100 & \\
\hline Jumlah & 19 & 42,2 & 26 & 57,8 & 45 & 100 & \\
\hline
\end{tabular}

Berdasarkan tabel distribusi responden berdasarkan pendidikan, sosial ekonomi, pekerjaan, perilaku ibu pengguna smartphone, dan perkembangan anak prasekolah di TK Harapan I Tahun 2017 menunjukan bahwa sebagian besar responden berpendidikan tamat SMA yaitu sebesar 60,0\% (27 orang), sebagian besar sosial ekonomi/penghasilan keluarga berada direntang 2.300.000-5.000.000 yaitu sebesar 51,1\% (23 orang), sebagian besar yang menjadi responden tidak bekerja yaitu 77,8\% (35 orang), sebagian besar responden memiliki perilaku penggunaan smartphone tinggi yaitu sebesar 55,6\% (25 orang), dan sebagian besar responden perkembangan anak prasekolah kategori suspect yaitu sebesar $57,8 \%$ (26 orang).

\section{PEMBAHASAN}

Berdasarkan analisa hubungan antara perilaku ibu pengguna smartphone terhadap perkembangan anak prasekolah di TK Harapan I. Hasil penelitian ini membuktikan bahwa terdapat hubungan yang siginifikan secara 
statistik antara perilaku ibu pengguna smartphone terhadap perkembangan anak prasekolah dengan nilai uji statistik didapatkan $P$ value $=0,014(\alpha<0,05)$. Penelitian tersebut sejalan dengan teori dari Kementrian Kesehatan (2014) yang menyatakan bahwa orang tua mempunyai peran strategis dalam mendidik dan membantu pertumbuhan dan perkembangan anak yaitu dengan cara berinteraksi dengan anak dengan penuh kasih sayang lewat berbagai macam kegiatan yang sesuai anak, orang tua dapat memberikan belaian, senyuman, dekapan, penghargaan dan bermain, mendongeng, menyanyi serta memberikan contoh-contoh tingkah laku sehari-hari yang baik dan benar kepada anak. Hal ini didukung dengan hasil penelitian yang dilakukan Nurlaila Nurchairina (2014) tentang pemberian stimulasi ibu yaitu 56,7\% responden memberikan stimulasi deng an baik dan 43,3\% kurang. Perkembangan balita dengan kategori sesuai 81,7\% dan tidak sesuai18,3\%. Ada sebanyak $91,2 \%$ ibu yang memberikan stimulasi dengan baik dan perkembangan balitanya sesuai. Sedangkan diantara ibu yang memberikan stimulasi kurang baik, ada 69,2\% yang perkembangan balitanya sesuai. Diperoleh nilai $\mathrm{p}$ value $=0,044$ dan $\mathrm{OR}=4,593$. Kesimpulan terdapat hubungan antara pemberian stimulasi ibu dengan perkembangan balita.

Penelitian yang dilakukan Lestari, Riana \& Taftarzim (2015) sejalan dengan hasil penelitian, dimana penggunaan smartphone dalam keluarga mempengaruhi keseluruhan interaksi sosial dalam keluarga tersebut. Dimana interaksi yang biasanya dilakukan antara orang tua pada anaknya sebagai bentuk pengasuhan dan komunikasi untuk menciptakan kekukuhan keluarga akan terganggu, hal tersebut dikarenakan keluarga merupakan kesatuan sistem yang utuh, dimana bila salah satu anggota keluarga mengalami kesulitan dalam melakukan interaksi secara langsung, hal tersebut membuat keluarga secara sadar atau tidak akan mengurangi atau melakukan perubahan dalam pola interaksi sosialnya.

Penelitian yang dilakukan Joni (2015) dengan metode yang digunakan dalam penelitiannya adalah deskriptif analititik dengan pendekatan cross sectional. Populasi penelitian ini sebanyak 30 anak. Pada penelitian ini sampel yang diambil secara total sampling. Penelitian dilakukan dengan penyebaran kuesioner dan lembar observasi. Hasil penelitian pola asuh diperoleh data pola asuh permisif sebanyak $36.7 \%$, pola asuh otoriter sebanyak 33,3\%, dan pola asuh demokratis sebanyak 30\%. Hasil observasi terhadap 30 anak $70 \%$ mengalami suspect dalam perkembangan bahasa dan 30\% normal dalam perkembangan bahasa. Dari hasil uji chi-square didapatkan hasil nilai $\mathrm{p}$ value 0,015 lebih kecil dari pada nilai $\alpha$ yaitu 0,05 . Terdapat hubungan antara pola asuh orang tua terhadap perkembangan bahasa anak.

Penelitian yang dilakukan Jafri \& Ovari (2015) dengan desain penelitian eksperimen dengan metode prosfektif mendukung penelitian diatas. Populasi anak berumur 36-71 bulan dengan jumlah sampel 65 responden. Instrument penelitian berupa kuesioner dan lembar observasi. Data diolah melihat distribusi frekuensi, nilai mean dan uji statistik Chi-Square Tes . Hasil penelitian didapatkan 1) Perkembangan sosialisasi kategori baik baik secara berturut-turut adalah sebanyak 87,0\% kelompok umur 36-47 bulan, 55,6\% kelompok umur 48-59 bulan dan 86,7\% kelompok umur 60-71 bulan. 2) Hasil uji statistik hubungan pemberian stimulasi dengan perkembangan sosialisasi pada kelompok umur 36-47 bulan diperoleh nilai $\mathrm{p}=0,01$ maka dapat disimpulkan ada hubungan yang bermakna antara pemberian stimulasi dengan perkembangan sosialisasi. Hasil uji statistik hubungan pemberian stimulasi dengan perkembangan sosialisasi pada kelompok umur 48-59 bulan diperoleh nilai $\mathrm{p}=0,04$ maka dapat disimpulkan ada hubungan yang bermakna antara pemberian stimulasi dengan 
perkembangan sosialisasi. Hasil uji statistik hubungan pemberian stimulasi dengan perkembangan sosialisasi pada kelompok umur 60-71 bulan diperoleh nilai $\mathrm{p}=0,01$ maka dapat disimpulkan ada hubungan yang bermakna antara pemberian stimulasi dengan perkembangan sosialisasi Hasil uji statistik ada hubungan pemberian stimulasi dengan perkembangan sosialisasi. Perkembangan personal sosial sangat dipengaruhi lingkungan dan interaksi antara anak dengan orang tua/orang dewasa lainnya. Perkembangan anak akan optimal bila interaksi sosial sesuai kebutuhan anak pada berbagai tahap perkembangannya. Peneliti menyimpulkan orang tua khususnya ibu memiliki peran strategis dalam mendidik dan membantu pertumbuhan dan perkembangan anak, salah satu cara adalah memberi stimulus pada anak. Karena stimulus sangat berpengaruh pada perkembangan anak. Perkembangan anak akan optimal apabila interaksi anak sesuai dengan kebutuhan anak pada tahap perkembangannya. Salah satu yang mempengaruhi interaksi sosial khususnya dalam keluarga adalah penggunaan smartphone. Penggunaan smartphone oleh ibu merubah peran ibu dalam keluarga, salah satunya memberikan strimulus pada anak, sehingga ini akan berdampak pada perkembangan anak prasekolah.

\section{KESIMPULAN DAN REKOMENDASI}

Kesimpulan dibuat berdasarkan pada tujuan khusus dari hasil penelitian beserta analisis univariat dan bivariat yang telah dilakukan yang berasal dari subjek penelitian dengan 45 responden, adapun kesimpulan dalam penelitian ini yaitu Rata-rata usia responden adalah 30,29 tahun dengan usia termuda adalah 25 tahun dan usia tertua adalah 40 tahun, berdasarkan pendidikan sebagian besar responden berpendidikan tamat SMA yaitu sebesar 60,0\% (27 orang), berdasrkan sosial ekonomi sebagian besar sosial ekonomi/ penghasilan keluarga berada direntang 2.300.000-5.000.000 yaitu sebesar 51,1\% (23 orang), berdasrkan pekerjaan sebagian besar yang menjadi responden tidak bekerja yaitu 77,8\% (35 orang) Responden memiliki perilaku penggunaan smartphone tinggi yaitu sebesar 55,6\% (25 orang); Untuk perkembangan anak sebagian besar perkembangan anak prasekolah mengalami suspect yaitu sebesar 57,8\% (26 orang); Adanya hubungan yang bermakna antara perilaku ibu pengguna smartphone terhadap perkembangan anak prasekolah dari hasil uji statistik didapatkan $p$ value $=0,014$ dan nilai $\mathrm{OR}=5,881$ (95\% CI.1,605-21,552). Rekomendasi Bagi Orang tua khusus nya untuk ibu diharapkan dalam penggunaan smartphone dengan bijak sehingga ibu memiliki waktu lebih banyak untuk mendampingi anak untuk melatih kemampuan anak, khususnya kemampuan anak yang belum optimal. Diharapkan para ibu mampu berkomitmen 2 jam tanpa smartphone per hari. Bagi pihak TK diharapkan bias dijadikan bahan masukan kepada orang tua apabila memang anak dari orang tua tersebut mengalami keterlambatan di banding dengan teman-temannya. Bagi Peneliti Selanjutnya diharapkan melakukan penelitian dengan jenis multivariate dan metode kualitatif dengan wawancara kepada ibu sehingga mendapatkan data secara kuantitas dan kualitas.

\section{REFERENSI}

1) Jafri, Yendrizal. \& Ovari, Isna. (2015). Hubungan Pemberian Stimulasi Sosialisasi dengan Perkembangan Sosialisasi pada Anak Prasekolah Umur 3-6 Tahun di Posyandu Kelurahan Pintu Kebun Kota Bukittinggi Tahun 2015. Diperoleh pada tangga 24 Mei 2017 dari http://stikesperintis.ac.id// 
2) Joni. (2015). Hubungan Pola Asuh Orang Tua Terhadap Perkembangan Bahasa Anak Prasekolah (3-5 Tahun) Di Paud Al-Hasanah Tahun 2014. Diperoleh pada tanggal 21-07-2017 dari http://journal.stkiptam.ac.id/

3) Kementrian Kesehatan Republik Indonesia. 2014. Orang Tua Kunci Utama Tumbuh Kembang Anak. Diperoleh pada tanggal 15 Juni 2017 dari http://www.depkes.go.id

4) Lestari, Inda., Riana, Agus. W., \& Taftarzami, Budi. M. (2015). Pengaruh Gadget Pada Interaksi Sosial Dalam Keluarga, volume 2, 204-209. Di peroleh pada tanggal 06 Juni 2017, dari http://fisip.unpad.ac.id/

5) Lusiana. (27 Maret 2016). Ibu Sibuk dengan Ponsel, Tumbuh Kembang Anak Jadi Terhambat. National Gergraphic Indonesia. Diperoleh pada tanggal 04 Mei 2017 dari http://nationalgeographic.co.id/

6) Medise, Bernie. E., 2013. Mengenal Keterlambatan Perkembangan Umum Pada Anak. Ikatan Dokter Anak Indonesia. Diperoleh pada tanggal 05 Mei 2017 dari http://www.idai.or.id/

7) Nurlela., \& Nurchairina. (2014). Pemberian Stimulasi Oleh Ibu Untuk Perkembangan Balita. Jurnal Keperawatan. Diperoleh pada tanggal 13 April 2017 dari http://ejurnal.poltekkes-tjk.ac.id/

8) Nursalam. (2016). Metodelogi Penelitian Ilmu Keperawatan Pendekatan Praktis (Edisi 4).Jakarta: Salemba Medika

9) Wulandari, Retno., Ichsan, Burhannudin., Romadhon, Y.A. 2016. Perbedaan Perkembangan Sosial Anak Usia 3-6 Tahun Dengan Pendidikan Usia Dini Dan Tanpa Pendidikan Usia Dini Di Kecamatan Peterongan Jombang. Biomedika Fakultas Kedoktean. Diambil 13 april 2017 dari http://journals.ums.ac.id/ 